\title{
Comparing endemism and habitat restriction in Mesoamerican tropical deciduous forest birds: implications for biodiversity conservation planning
}

\author{
CALEB E. GORDON and JUAN FRANCISCO ORNELAS
}

\begin{abstract}
Summary
Biogeographical endemism and habitat restriction are two easily measured quantities that can be used as indicators of species' ecological restrictions. We analysed and compared these two types of information from available literature sources in an attempt to identify all bird species critically dependent on tropical deciduous forests of western Mexico and Central America. Based on patterns of biogeographical restriction, we identified 42 endemics, 33 disjunct endemics, 59 corridor species and 3 seasonal endemics associated with tropical deciduous forest (TDF) in this region. Based on patterns of habitat use in these species, we classified them as 50 tropical deciduous forest-restricted species and 82 apparent habitat generalist species. No habitat use information was available within the TDF belt for five of the biogeographically restricted species. We found a high proportion of apparent habitat generalists $(60 \%)$ among biogeographically restricted species. We discuss three specific scenarios in which species critically dependent on TDF may nonetheless appear generalized in their patterns of habitat use. These species are termed "cryptic habitat specialists." The proportion of apparent habitat generalists is highly variable among biogeographical regions and habitat types. Thus, global biodiversity conservation prioritizations that rely on habitat restriction as an indicator of ecological sensitivity may underestimate conservation needs within bioregions that contain high proportions of cryptic habitat specialists.
\end{abstract}

El endemismo biogeográfico y la restricción en uso de hábitat pueden indicar que tan restringidas están las especies de aves en sus requerimientos ecológicos. En un intento por identificar a todas las especies de aves que dependen críticamente de los bosques tropicales deciduos del occidente de México y Centroamérica, analizamos y comparamos estos dos tipos de información en la literatura. Identificamos 42 especies endémicas, 33 endémicas pero con una distribución disyunta, 59 especies que extienden su distribución a otra región a través de un corredor, y 3 que son endémicas solo estacionalmente a la región del bosque tropical deciduo. Basados en los patrones de uso de hábitat de estas especies, las dividimos en dos categorías: especies restringidas al bosque tropical deciduo (50 especies) y especies aparentemente generalistas en el uso de hábitat (82 especies). No hubo información disponible sobre el uso de habitat de 5 de las especies biogeográficamente restringidas. Encontramos una alta proporción $(60 \%)$ de generalistas entre aquellas especies que están restringidas biogeográficamente. Discutimos tres escenarios específicos en los cuales las especies críticamente dependientes de los bosques tropicales deciduos pueden parecer como generalistas en sus patrones de uso de hábitat. Estas especies son denominadas como "especialistas crípticas de hábitat" y son 
identificadas exitosamente como especialistas mediante el uso de información biogeográfica, mientras que la información sobre uso de hábitat las identificaria incorrectamente como generalistas. Por otro lado, la proporción de generalistas aparentes de hábitat es altamente variable entre regiones biogeográficas y tipos de hábitat. Por ello, dado que los esquemas de priorización en la conservación de biodiversidad global se establecen utilizando la restricción de hábitat como un indicador de susceptibilidad ecológica, las necesidades de conservación se pueden subestimar entre regiones y ecosistemas que contienen una alta proporción de especialistas crípticos de hábitat, tales como los bosques tropicales deciduos.

\section{Introduction}

A central task of conservation biology is to provide a scientific basis to direct efforts towards conserving biological diversity. Conservation prioritization schemes accomplish this end by synthesizing biological information to identify the areas most in need of conservation efforts (Sisk et al. 1994, Johnson 1995). Conservation priorities are based on one or more of the following factors: (1) the extent of biodiversity contained in particular regions or ecosystems; (2) the biogeographical or phylogenetic uniqueness of that biodiversity; (3) the ecological sensitivity/threatened status of that biodiversity. The need for such prioritization techniques is particularly critical in areas such as the Neotropics, where the pace of anthropogenic ecological disturbance is rapid and potential biodiversity losses are great.

Including a measure of the ecological sensitivity of organisms (factor 3 ) in such prioritization schemes complements analysis of biogeographical and phylogenetic diversity (factors 1 and 2) by indicating the current or potential impacts of anthropogenic disturbance on biodiversity in particular areas (e.g. Daniels et al. 1991, Ceballos and García 1995, Stotz et al. 1996, Rodríguez and Rojas-Suárez 1996). The ideal way to assess ecological sensitivity in a particular bioregion would be to study the ecological requirements of each species in detail. Given that this is practically impossible, shortcuts are needed. Analyses of biogeographical restriction and habitat restriction constitute two such shortcuts. Both of these variables can be readily quantified because they are commonly reported in literature and are relatively well known for birds. These variables are, in essence, spatial restrictions that should reflect species' ecological restrictions. Species with the narrowest ecological restrictions should be the most sensitive to ecological disturbance and alteration.

We used available literature to compile evidence of biogeographical and habitat-level restrictions for all bird species of western Mesoamerican tropical deciduous forests. Our goals were twofold. The first was to identify the species that are critically dependent on tropical deciduous forest, meaning that they require tropical deciduous forest habitat for survival, and are therefore threatened by the destruction of this habitat type. The second was to discuss the utility of biogeographical and habitat use information as indicators of ecological sensitivity in the assessment of biodiversity conservation priorities. 
The TDF belt study system

Tropical deciduous forest (TDF) occurs in several regions of the Neotropics, but the preponderance of this habitat type in the New World occurs in a region hereafter referred to as the TDF belt. This is a band of lowlands on the Pacific slope of Mexico and northern Central America, stretching more or less continuously from southern Sonora, Mexico, to Guanacaste, Costa Rica. The TDF belt has commonly been identified as a distinct biogeographical province based on its characteristic vegetative phenology, distinctive flora and fauna, and geographical isolation from areas with similar habitat (Rzedowski 1978, Ceballos and García 1995, Stotz et al. 1996). TDF occurs between o and 1,500 $\mathrm{m}$ elevation in this region. The annual average rainfall, which ranges from 600 to $1,200 \mathrm{~mm}$, is distributed almost exclusively in a summer wet season (Rzedowski 1978). These conditions support a dense, closed-canopy, broadleaved forest in which most plants lose their leaves during the 5-8 month winter dry season (Rzedowski 1978). The TDF belt is known for its high biodiversity and proportionally high levels of endemism in many taxa (Ceballos and García 1995). Recent reviews of biodiversity patterns and conservation priorities in the TDF belt can be found in Ramamoorthy et al. (1993), Bojórquez-Tapia et al. (1995), Bullock et al. (1995), Ceballos and García (1995) and Stotz et al. (1996).

\section{Methods}

We used published literature to compile a list of all bird species either endemic or semi-endemic to the TDF belt. We excluded species of aquatic habitats. Endemic species were defined as those whose world-wide geographical distributions are entirely inside the TDF belt. Semi-endemic species fit into one of three categories: (1) "seasonal endemics", latitudinally migratory species whose geographical range fits entirely inside the TDF belt during a certain time of year; (2) "corridor species", species whose geographical range corresponds exclusively to the TDF belt for a significant $(>300 \mathrm{~km}$ ) portion, but also extends continuously into other biogeographical regions; (3) "disjunct endemics", species with a geographically isolated population restricted to the TDF belt. We followed American Ornithologists' Union taxonomy (AOU 1998). We then compiled habitat use information for all of these species from 13 literature sources on TDF belt avifaunas (Figure 1).

For the species identified as endemic or semi-endemic to the TDF belt, a simple synthesis of all available habitat-use information was conducted as follows. Each species was assigned a habitat number for each literature source that contained adequate information for that species. If the species was recorded exclusively in TDF in a particular study, then it was assigned a value of 1 for that study. If the species was recorded in disturbed or regenerating TDF, or in habitat types other than TDF, it was assigned a value of -1 (see Appendix for more detailed scoring and inclusion criteria). These habitat scores were then summed across studies for each species to obtain a total habitat number for each species. For semi-endemic species, the total habitat number was calculated using only information from within the TDF belt. All species with a positive total habitat number were classified as TDF-restricted species. All species with a total habitat number equal to, 


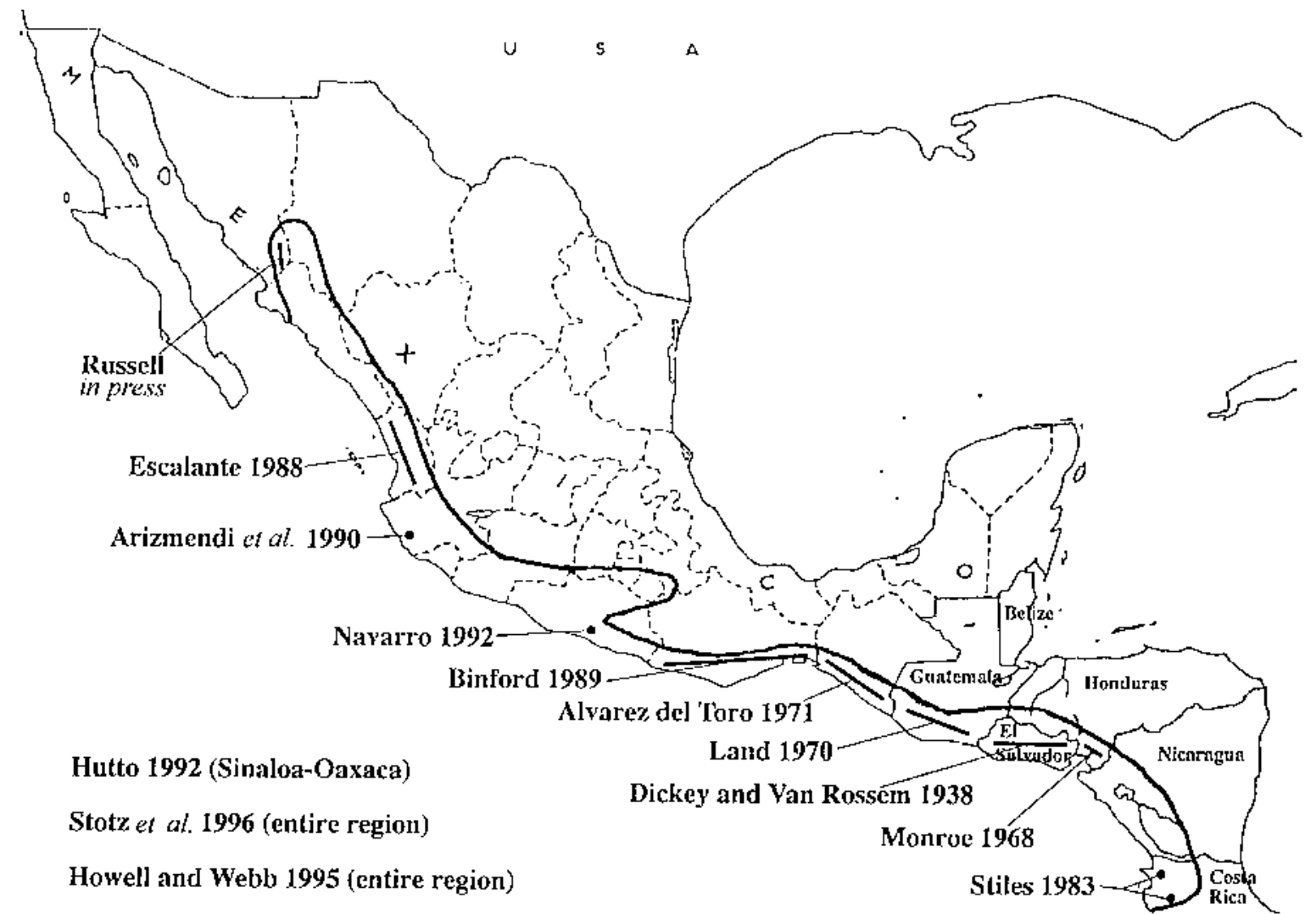

Figure 1. The tropical deciduous forest belt of Pacific Mexico and Central America (indicated by thick black line), showing the areas of coverage for each of the 13 sources of habitat use information used in this study. The extent of spatial coverage for each habitat use literature source is either described in the text or is indicated by points or bars. 
Table 1. Summary of biogeographical and habitat analysis for bird species endemic or semi-endemic to the west Mexican/Mesoamerican tropical deciduous forest (TDF) belt. Numbers represent the number of species in each category

\begin{tabular}{lllll}
\hline & $\begin{array}{l}\text { TDF-restricted } \\
\text { species }\end{array}$ & $\begin{array}{l}\text { Apparent } \\
\text { habitat } \\
\text { generalists }\end{array}$ & Unknown & Total \\
\hline Endemics & 17 & 25 & 1 & 42 \\
$\begin{array}{l}\text { Semi-endemics } \\
\text { Disjunct }\end{array}$ & 18 & 14 & 33 & 3 \\
$\quad$ Seasonal & 15 & 3 & 4 & 59 \\
$\quad$ Corridor & 50 & 82 & 5 & 137 \\
Total & & & & 37 \\
\hline
\end{tabular}

or less than zero, but with at least some habitat use information available, were classified as apparent habitat generalists.

\section{Results}

In the biogeographical analysis, we identified 137 species with patterns of restriction to the TDF belt. These consisted of 42 endemic and 95 semi-endemic species. We further classified the semi-endemics as 33 disjunct endemics, 3 seasonal endemics, and 59 corridor species.

The analysis of habitat use for these species resulted in the following classification: 50 TDF-restricted species, 82 apparent habitat generalists and 5 species with unknown habitat use (Table 1, Appendix).

\section{Discussion}

\section{Biogeography}

For TDF belt endemics, the pattern of biogeographical restriction suggests, but does not automatically imply, a narrow adaptation to TDF. It should be noted that 42 TDF belt endemic species is a conservative number because a number of additional bird subspecies are endemic to the TDF belt, some of which have been elevated to species status by some authors (e.g. "Doubleday's Hummingbird" Cynanthus doubledayi, "Cinnamon-sided Hummingbird" Amazilia wagneri, Howell and Webb, 1995).

The large number of disjunct endemics in the TDF belt reflects both the uniqueness of the west-Mexican lowland avifauna and the complexity of the biogeography and taxonomy of birds in this region. Although this endemic diversity is not currently classified at the species level, it is important to identify and consider these species for conservation because the taxonomic decisions themselves may be somewhat arbitrary and subject to debate. How much do these endemic populations add to the biodiversity conservation value of the TDF belt? Rojas (1992) noted that focusing on the species level for conservation has the effect of devaluing isolated and differentiated forms. This may be particularly problematic for forms endemic to distinct biogeographical regions such as the TDF belt, because in many cases, taxa are not elevated to species level if they are 
completely allopatric from their closest relatives (Hazevoet 1996). In 21 of the 33 disjunct endemics, the TDF belt endemic form has been described as a distinct subspecies (Appendix). For one additional species, plumage characters are unique to the TDF belt endemic form (Appendix). This suggests that the TDF endemic populations of the disjunct endemics represent substantial biodiversity unique to the region.

The few species classified as TDF belt seasonal endemics are all endemic to this region during winter. Western Mexico is known for its high abundance and diversity of wintering Neotropical-Nearctic migrants (Hutto 1992). However, the low number of TDF belt winter endemics, and the apparent habitat generality of the three that are seasonally endemic (Appendix), reflect the tendency of most such migrants to have wide distributions both in terms of biogeography and habitat use (but see Gómez de Silva 1996). This result confirms a pattern emerging from many recent studies, namely that wintering Nearctic-Neotropical migrants tend to be habitat generalists during winter, often reaching their highest abundances in disturbed habitats (Lynch 1992, Petit et al. 1992, Ornelas et al. 1993, Hutto 1995).

The large number of corridor species reflects the avifaunistic connection between the TDF belt and other tropical lowland ecosystems. Many of these species are restricted to the TDF belt over most of Mexico, but also extend continuously into more humid lowland regions in southern and eastern Mexico and Central America. A high percentage of these species were identified as apparent habitat generalists (Table 1), and many of these may be true generalists in the sense of Figure 2B. Though not as important as TDF belt endemics sensu stricto, corridor species also add to the conservation value of TDF to some extent. Fifteen corridor species have TDF belt endemic subspecies, and one more has plumage characters unique to the TDF belt form (Appendix), suggesting that the TDF belt contains unique genetic diversity in these species. Even for the many corridor species without obvious genetic diversity unique to the region, the TDF belt is valuable for the substantial peripheral extensions of their geographical ranges (Lesica and Allendorf 1995).

\section{Habitat use}

We found a high proportion (6o\%) of apparent habitat generalists among the TDF belt endemics. These included many species that best characterize the endemic TDF belt avifauna. One possible explanation for this pattern is that many of the TDF belt endemics are truly habitat generalists, capable of sustaining populations in a variety of habitat types (Figure $2 \mathrm{~B}$ ). An alternative explanation is that many of these species are actually just as narrowly adapted to, and critically dependent on, TDF habitat as are the habitat-restricted endemics. We refer to such species as cryptic habitat specialists because their apparently generalized habitat use patterns belie the specificity of their habitat requirements. For biodiversity conservation planning, these species should be considered just as sensitive as habitat-restricted species.

Our results suggest three types of bird life histories that might lead to cryptic habitat specialization. The first type includes species that explore extensive areas during their normal daily movement patterns (Figure $2 \mathrm{C}$ ). Species that forage for 

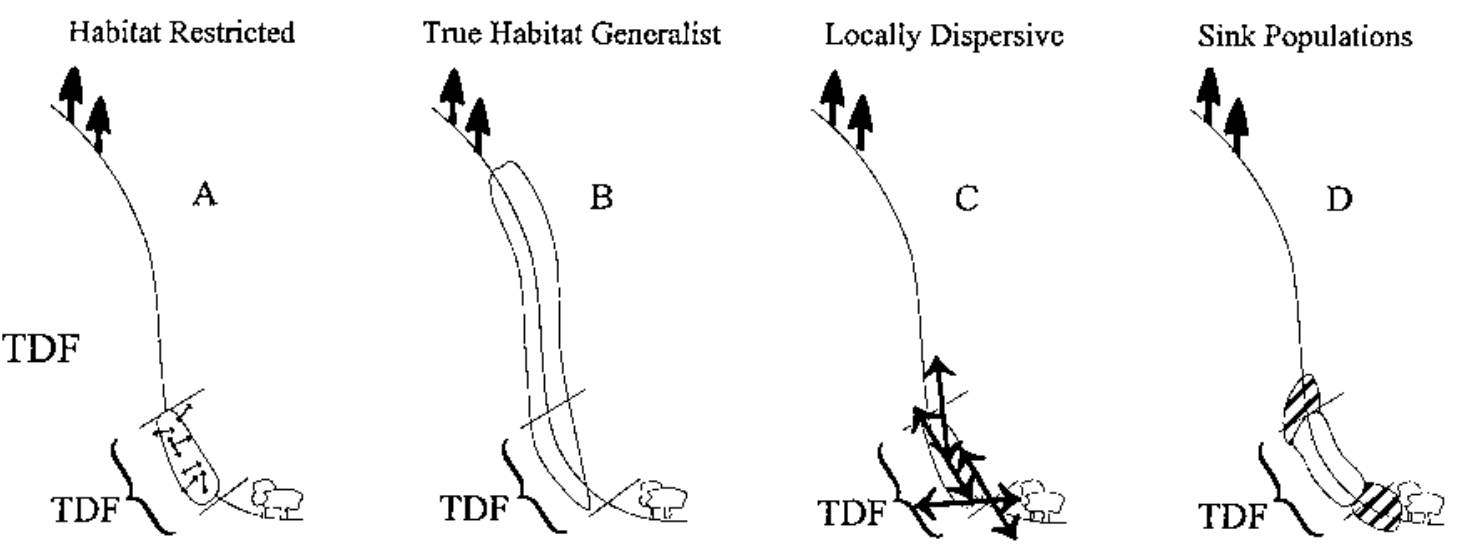

Altitudinal Migrant

Figure 2. Patterns of habitat use and habitat specialization. The curves represent altitudinal gradients of habitats with tropical deciduous forest (TDF) occurring in between the two lines near the bottom. Encircled areas represent the areas in which a particular species can be found. Hashing indicates areas in which the species of interest can be found but does not breed. Arrows represent daily foraging movements of individuals in A and C, and seasonal movements of individuals in E. Examples B through E would be classified as habitat generalists based on habitat use patterns even though cryptic habitat specialists (examples $C$ through E) may be just as specialized and dependent on TDF habitat as the habitat-restricted case represented by example A. 
patchy or rare resources such as fruit, nectar, carrion or large vertebrate prey may need to cover large areas on a daily basis in search of food. Such mobile species perceive the environment in coarser grain than do less mobile species, and are more likely to cross the lines that we arbitrarily ascribe as the boundaries between habitat types. This does not necessarily mean that they have ecological requirements any less stringent than more sedentary species. On the contrary, if they are searching for rarer resources they may be more sensitive to ecological disturbance than species that can acquire all the resources they need inside a small territory. Ornelas and Arizmendi (1995) suggested that the Yellow Grosbeak Pheucticus chrysopeplus and the Orange-fronted Parakeet Aratinga canicularis exemplify this pattern among TDF belt birds. This phenomenon may explain the large proportion of raptors and owls classified as apparent habitat generalists in our analysis. Fourteen of $18(78 \%)$ raptor and owl species included in our study were classified as apparent generalists, compared with 68 of 119 (57\%) among all other species (Appendix).

Another phenomenon that may produce cryptic habitat specialists is sourcesink habitat selection dynamics (Figure 2D, Pulliam 1988). In this scenario, individuals from source populations in a single habitat type spill over into sink populations in one or more alternative habitat types in the surrounding landscape. Because sink habitats, by definition, are not capable of sustaining viable populations on their own, they should not be considered to constitute viable areas for conserving these species. Source-sink habitat selection dynamics have rarely been documented in the field, and examples of this phenomenon are not known from the TDF belt.

A third phenomenon that can produce cryptic habitat specialists is altitudinal migration (Figure $2 \mathrm{E}$ ). This behaviour is prevalent in bird communities of the TDF belt and throughout the tropics. Altitudinal migration has been explained as a way for species to track seasonally fluctuating food resources such as nectar and fruit (Loiselle and Blake 1991, Ornelas and Arizmendi 1995). Altitudinal migrants (or more generally, between-habitat migrants) rotate among habitat types on an annual cycle (e.g. Powell and Bjork 1995). As such, they demonstrate an apparently generalized pattern of habitat use. However, they may be as ecologically sensitive as single-habitat specialists if they are narrowly adapted to using a single habitat type during any one season. Furthermore, they may be even more narrowly adapted and ecologically sensitive than single-habitat specialists if their survival depends on the maintenance of multiple habitats or an uninterrupted juxtaposition of those habitats in the landscape (Loiselle and Blake 1991). TDF belt species described as altitudinal migrants are indicated in the Appendix. Surprisingly, the proportion of these 19 species classified as apparent habitat generalists is very similar to the proportion of apparent habitat generalists among the other 118 species (63\% vs. 59\%). This may reflect the conservativeness of our analysis with respect to scoring species as apparent habitat generalists. Using the criterion that all species ever recorded in habitats other than TDF are apparent habitat generalists, only 26 of the 137 biogeographically restricted species would be classified as habitat restricted.

It should be noted that only one or a few literature sources contained habitat use information for many of the species in our analysis. This undoubtedly contributes to a certain degree of error inherent in our habitat use classification. 
However, this paucity of habitat use information is typical for most areas of the Neotropics. This underscores the limited utility of habitat use information as an indicator of ecological sensitivity.

\section{Significance for conservation planning}

If the proportion of cryptic habitat specialists was roughly constant across bioregions, then this would not affect the prioritization of bioregions in global conservation planning schemes. It appears that this is not the case for birds in the Neotropics, however. In the data of Stotz et al. (1996) for all Neotropical bird species, the percentage of the bioregional endemics that are habitat restricted ranges from $100 \%$ to $18 \%$ among zoogeographical provinces, with an average of $45 \%$. The TDF belt ranks fifteenth out of 22 with a value of $36 \%$. This is roughly consistent with our value of $40 \%$. Lumping these zoogeographical provinces into major Neotropical habitat types, Stotz et al. report percentages ranging from $47 \%$ to $9 \%$. Tropical deciduous forest is ranked ninth out of 10 with $21 \%$ of bioregional endemic species being habitat restricted.

Thus habitat restriction is not randomly distributed, but varies systematically across zoogeographical provinces. TDF provinces have particularly high percentages of apparent habitat generalists among their endemic species. Given our limited knowledge of the movement patterns of birds in the Neotropics, it is unreasonable to assume that this variation exclusively reflects variation in true habitat generalization. One potential explanation for this pattern is that the extreme seasonality of TDF has promoted seasonal movements between habitat types in many of its endemic birds. Another possibility is that species in the TDF belt frequently cross boundaries between habitat types because habitats are heterogeneous on a very fine spatial scale in this region, owing to the extreme topographical relief of the Pacific slope of western Mexico and northern Central America. In any event, the bioregional endemism of these species suggests that many are less ecologically generalized than their patterns of habitat use would indicate.

This demonstrates a potential pitfall of using habitat use information in conservation prioritization schemes. Analyses that use habitat restriction as an indicator of ecological vulnerability or extinction risk undervalue bioregions with high proportions of cryptic habitat specialists.

This leaves the issue of how to assess accurately ecological sensitivity for biodiversity conservation planning. In the absence of dietary information and measurement of local and migratory movement patterns for all species, habitat use information must be used with caution. In addition to mislabelling cryptic habitat specialists, habitat restriction is also a more subjective criterion than is biogeographical restriction, and may therefore be subject to additional bias (compare the conservativeness of Howell and Webb's (1995) scoring with that of Escalante (1988) in the Appendix). Biogeographical restriction is not subject to these biases. We suggest that the number of bird taxa endemic to the TDF belt reflects the conservation value of this bioregion more accurately than does the number of habitat-restricted endemics. In general, biogeographical information should be weighted more heavily than habitat use information in global biodiversity conservation prioritization systems. Habitat use information may be helpful as an 
ancillary piece of information, but only when it can be viewed in the appropriate context of species' foraging, migration and dietary needs.

\section{Acknowledgements}

We would like to thank Stephen M. Russell for many helpful discussions on tropical deciduous forest birds. We also thank Douglas Stotz, A. Townsend Peterson, Robert H. Robichaux, Carlos Martinez del Rio, and several anonymous reviewers for helpful comments on earlier versions of the manuscript.

Appendix. Habitat-use scores and classification of the 137 bird species identified as endemics or semi-endemics of the west Mexican/Mesoamerican tropical deciduous forest (TDF) belt.

\begin{tabular}{|c|c|c|c|c|c|c|c|c|c|c|c|c|c|c|}
\hline & \multicolumn{14}{|c|}{ Literature source } \\
\hline & A & $\mathrm{B}$ & $\mathrm{C}$ & $\mathrm{D}$ & $\mathrm{E}$ & $\mathrm{F}$ & G & $\mathrm{H}$ & I & $\mathrm{J}$ & K & $\mathrm{L}$ & M & thn \\
\hline \multicolumn{15}{|l|}{ Endemics } \\
\hline \multicolumn{15}{|l|}{ TDF-restricted species } \\
\hline Ortalis poliocephala (AM) & & & $x$ & & $\mathrm{r}$ & $\mathrm{r}$ & $\mathrm{r}$ & & $\mathrm{r}$ & $x$ & & $x$ & & 1 \\
\hline Trogon citreolus & & & $\mathrm{r}$ & & $\mathrm{r}$ & & $\mathrm{r}$ & $\mathrm{r}$ & & $x$ & & $x$ & & 2 \\
\hline Momotus mexicanus & & $\mathrm{r}$ & & & $\mathrm{r}$ & $\mathrm{r}$ & & $x$ & & $x$ & & $x$ & $\mathrm{r}$ & 1 \\
\hline Deltarhynchus flammulatus & & & & & $\mathrm{r}$ & $\mathrm{r}$ & $\mathrm{r}$ & $x$ & & $\mathrm{r}$ & & $\mathrm{r}$ & & 4 \\
\hline Chiroxiphia linearis & $x$ & & & $\mathrm{r}$ & $\mathrm{r}$ & $\mathrm{r}$ & & & & $\mathrm{x}$ & $\mathrm{r}$ & $x$ & $\mathrm{r}$ & 2 \\
\hline Vireo hypochryseus & & & $\mathrm{r}$ & & $\mathrm{r}$ & & $\mathrm{r}$ & $x$ & $\mathrm{r}$ & $\mathrm{r}$ & & $x$ & & 3 \\
\hline Calocitta formosa & $x$ & & $\mathrm{r}$ & $\mathrm{r}$ & $\mathrm{r}$ & $\mathrm{r}$ & $\mathrm{r}$ & & $\mathrm{r}$ & $x$ & $x$ & $x$ & $x$ & 1 \\
\hline Cyanocorax sanblasianus & & & $x$ & & & & $\mathrm{r}$ & $\mathrm{r}$ & & $\mathrm{r}$ & & $x$ & & 1 \\
\hline C. beecheii & & $\mathrm{r}$ & & & & & & $\mathrm{r}$ & & $\mathrm{r}$ & & $x$ & & 2 \\
\hline Thryothorus pleurostictus & & & & $x$ & $\mathrm{r}$ & $\mathrm{r}$ & & & & $\mathrm{r}$ & $\mathrm{x}$ & $\mathrm{r}$ & $\mathrm{r}$ & 3 \\
\hline Polioptila nigriceps & & $x$ & & & & & $\mathrm{r}$ & $\mathrm{r}$ & & $\mathrm{r}$ & & $\mathrm{r}$ & & 3 \\
\hline Turdus rufopalliatus (AM) & & $\mathrm{r}$ & $\mathrm{r}$ & & $\mathrm{r}$ & & $\mathrm{r}$ & $\mathrm{r}$ & $\mathrm{r}$ & $\mathrm{r}$ & & $x$ & & 6 \\
\hline Granatellus venustus & & & $\mathrm{r}$ & & $\mathrm{r}$ & $\mathrm{r}$ & & $\mathrm{r}$ & & $\mathrm{r}$ & & $\mathrm{r}$ & & 6 \\
\hline Aimophila sumichrasti & & & & & $\mathrm{r}$ & & & & & $\mathrm{r}$ & & $\mathrm{r}$ & & 3 \\
\hline Passerina rositae & & & & & $\mathrm{r}$ & $\mathrm{r}$ & & & & $\mathrm{r}$ & & $\mathrm{r}$ & & 4 \\
\hline P. leclancherii & & & $x$ & & $\mathrm{r}$ & $\mathrm{r}$ & $\mathrm{r}$ & & & $\mathrm{r}$ & & $x$ & & 2 \\
\hline Cacicus melanicterus & & & $\mathrm{r}$ & & $\mathrm{r}$ & $\mathrm{r}$ & $\mathrm{r}$ & $x$ & $\mathrm{r}$ & $x$ & & $x$ & & 2 \\
\hline \multicolumn{15}{|l|}{ Apparent habitat generalists } \\
\hline Ortalis wagleri & & $x$ & & & & & & $\mathrm{r}$ & & $\mathrm{r}$ & & $x$ & & $\mathrm{o}$ \\
\hline O. leucogastra & $\mathrm{x}$ & & & & & $x$ & & & & $x$ & & $x$ & $x$ & -5 \\
\hline Callipepla douglasii & & $x$ & & & & & $\mathrm{r}$ & $x$ & & & & $x$ & & -2 \\
\hline Philortyx fasciatus & & & & & & & & & & $x$ & & $x$ & & -2 \\
\hline Aratinga strenua & $\mathrm{x}$ & & & & & & & & & $x$ & & $x$ & $x$ & -4 \\
\hline A. canicularis (AM) & $x$ & & $x$ & $\mathrm{r}$ & $\mathrm{r}$ & & $\mathrm{r}$ & $x$ & $x$ & $x$ & $x$ & $x$ & $x$ & -5 \\
\hline Forpus cyanopygius & & $x$ & & & & & & $\mathrm{r}$ & & $x$ & & $x$ & & -2 \\
\hline Amazona finschi & & $\mathrm{r}$ & $x$ & & $x$ & & $\mathrm{r}$ & $\mathrm{r}$ & & $x$ & & $x$ & & -1 \\
\hline Morococcyx erythropygus & $x$ & & & $x$ & $\mathrm{r}$ & & & $\mathrm{r}$ & & $x$ & & $x$ & $x$ & -3 \\
\hline Otus seductus & & & & & & & & & & $x$ & & $x$ & & -2 \\
\hline O. cooperi & & & & $\mathrm{r}$ & $x$ & $x$ & & & & $x$ & & $x$ & & -3 \\
\hline Glaucidium palmarum & & $\mathrm{r}$ & & & $\mathrm{r}$ & & & $\mathrm{x}$ & & & & $x$ & & $\mathrm{O}$ \\
\hline Chlorostilbon auriceps (AM) & & & $x$ & & $x$ & & $\mathrm{r}$ & $x$ & & & & $x$ & & -3 \\
\hline Amazilia cyanura & $\mathrm{r}$ & & & & & $x$ & & & & $x$ & $x$ & $x$ & $\mathrm{r}$ & -2 \\
\hline A. violiceps (AM) & & $\mathrm{r}$ & & & $x$ & & & $\mathrm{r}$ & & $x$ & & $x$ & & -1 \\
\hline Heliomaster constantii (AM) & $x$ & $\mathrm{r}$ & & $x$ & $\mathrm{r}$ & $x$ & $\mathrm{r}$ & $\mathrm{r}$ & & $\mathrm{r}$ & & $x$ & $x$ & $\mathrm{o}$ \\
\hline Melanerpes chrysogenys & & & $x$ & & $\mathrm{r}$ & & $\mathrm{r}$ & $\mathrm{r}$ & & $x$ & & $x$ & & $\mathrm{o}$ \\
\hline Tyrannus crassirostris & & $x$ & $\mathrm{r}$ & & $x$ & $\mathrm{r}$ & $\mathrm{r}$ & $x$ & & $\mathrm{r}$ & & $x$ & & $\mathrm{o}$ \\
\hline Calocitta colliei & & $x$ & $\mathrm{r}$ & & & & & $\mathrm{r}$ & & $x$ & & $x$ & & -1 \\
\hline Corvus sinaloae & & $x$ & & & & & & $\mathrm{r}$ & & $x$ & & $x$ & & -2 \\
\hline
\end{tabular}


Appendix. Continued.

\begin{tabular}{|c|c|c|c|c|c|c|c|c|c|c|c|c|c|c|}
\hline & \multicolumn{14}{|c|}{ Literature source } \\
\hline & A & B & $\mathrm{C}$ & $\mathrm{D}$ & $\mathrm{E}$ & $\mathrm{F}$ & G & $\mathrm{H}$ & I & $\mathrm{J}$ & K & $\mathrm{L}$ & M & thn \\
\hline Thryothorus sinaloa & & $x$ & $x$ & & $\mathrm{r}$ & & $\mathrm{r}$ & $x$ & $\mathrm{r}$ & $\mathrm{r}$ & & $x$ & & o \\
\hline T. felix & & $x$ & $x$ & & $\mathrm{r}$ & & $\mathrm{r}$ & $\mathrm{r}$ & $\mathrm{r}$ & $x$ & & $x$ & & o \\
\hline Aimophila ruficauda & $x$ & & $\mathrm{r}$ & $x$ & $x$ & $x$ & $x$ & $x$ & & $x$ & & $x$ & $x$ & -8 \\
\hline Icterus pustulatus (AM) & $x$ & $x$ & $x$ & $x$ & $\mathrm{r}$ & $\mathrm{r}$ & $\mathrm{r}$ & $\mathrm{x}$ & & $x$ & & $x$ & & -4 \\
\hline I. pectoralis & $x$ & & & $x$ & $\mathrm{r}$ & $x$ & & & & $x$ & & $x$ & $x$ & -5 \\
\hline
\end{tabular}

Disjunct endemics

TDF-restricted species

Crypturellus cinnamomeus*

Crax rubra

Geotrygon montana (AM)

Aratinga holochlora*

Ara militaris

Amazona albifrons*

Otus guatemalae*

Amazilia rutila (AM)*

Synallaxis erythrothorax*

Attila spadiceus*

Uropsila leucogastra*

Parula pitiayumi*

Rhodinocichla rosea*

Arremonops rufivirgatus*

Saltator coerulescens*

S. atriceps*

Pheucticus chrysopeplus

$(\mathrm{AM})^{*}$

Cyanocompsa parellina*

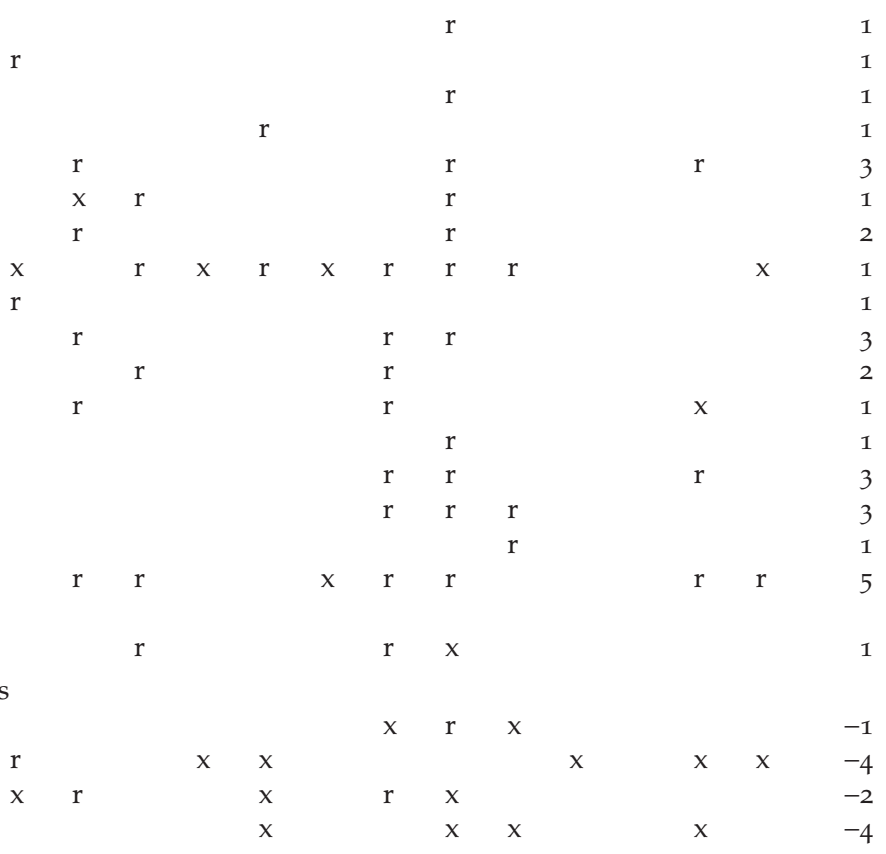

Apparent habitat generalists

Amazona oratrix

A. auropalliata

Geococcyx velox

Phaethornis superciliosus

$(\mathrm{AM})^{*}$

Trogon melanocephalus

Myiarchus nuttingi

Tityra semifasciata (AM)*

Campylorhynchus rufinucha* $\mathrm{x}$

Polioptila albiloris

Turdus assimilis (AM)**

Euthlypis lachrymosa

Habia rubica*

Euphonia affinis*

Icterus graduacauda (AM)*

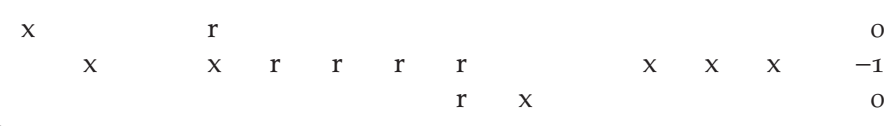

$\begin{array}{llll} & r & r & r \\ x & r & r & x\end{array}$

r

Seasonal endemics

Apparent habitat generalists

Archilochus alexandri (W)

Vireo atricapillus (W)

Vermivora luciae (W)

Corridor species

TDF-restricted species

Leptodon cayanensis

Buteogallus urubitinga 
Appendix. Continued.

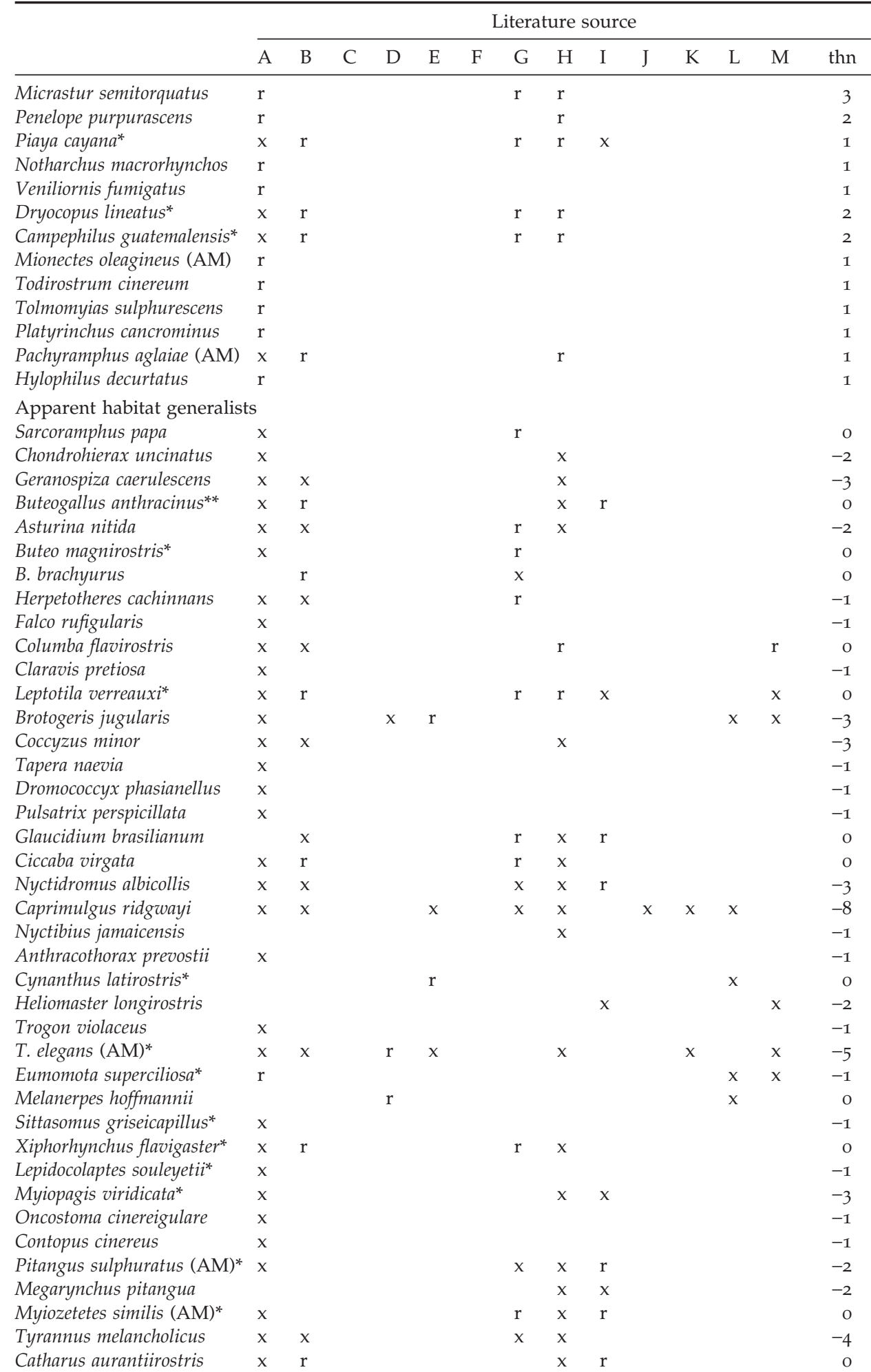


Appendix. Continued.

Literature source

\begin{tabular}{llllllllllllll}
\hline A & B & C & D & E & F & G & H & I & J & K & L & M & thn
\end{tabular}

No TDF belt habitat use information available

Pteroglossus torquatus corridor

Thryothorus maculipectus corridor

Ramphocaenus melanurus disjunct endemic

Icterus gularis* corridor

Amblycercus holosericeus corridor

* Subspecies endemic to TDF belt.

** Distinctive plumage character unique to TDF belt populations.

AM, Species identified as an altitudinal migrant by Ornelas and Arizmendi (1995), Levey and Stiles (1992), and/or Dickey and Van Rossem (1938).

$\mathrm{W}$, Species is a TDF belt endemic during winter only.

thn, total habitat number (summation of all previous columns).

Habitat use scoring: $x=-1$ (not restricted to TDF), $r=+1$ (restricted to TDF). If habitat use information from a particular literature source included information from outside the TDF belt region for a species, this species was not scored for this source.

Letter abbreviations and scoring and inclusion criteria for each habitat use literature source are as follows: A, Dickey and Van Rossem (1938), species assigned 1 if restricted to arid lowland life zone and found only in forested areas, species assigned -1 if found in other life zones and/or open disturbed areas; B, Russell (in press), species with accidental status not included, species assigned $I$ if found only in TDF and/or riparian habitat, species assigned -1 if found in second growth or open areas; C, Hutto (1992), species with fewer than 10 observations not included. Species assigned 1 if $>95 \%$ of observations were in mature TDF and/or thorn-scrub, species assigned -1 if at least $5 \%$ of observations were in any combination of pine-oak forest, disturbed TDF, or cloud-forest; D, Stiles (1983), information complied exclusively from Palo Verde and Santa Rosa localities, species with "o" or " $x$ " status (occasional or accidental) excluded. Species assigned 1 if observed only in woodland, forest interior, canopy, edge and / or riparian, species assigned -1 if observed in open, heavily altered, second growth, and/or tree plantation habitats; E, Binford (1989), species assigned 1 if found only in TDF, Pacific swamp forest, semi-deciduous forest and/or Isthmian scrub, species assigned -1 if found in interior arid scrub, mangroves, open areas, savannah, cloud-forest, and/or lowland evergreen forest; F, Alvarez del Toro (1971), species assigned 1 if found only in pacific region in wooded areas including Isthmian scrub, species assigned -1 if found in more humid forest types and/or in open or disturbed areas; G, Arizmendi et al. (1990), species with " $\mathrm{X}$ " or " $\mathrm{E}$ " status (casual or accidental) not included. Species assigned 1 if found only in upland TDF, matorral, and/or riparian semi-deciduous forest, species assigned -1 if found in open areas or mangrove/estuary; $\mathrm{H}$, Escalante (1988), several presumed accidental observations of species excluded (no abundance information given), species assigned 1 if found only in TDF, semi-deciduous forest, and/or palm forest, species assigned -1 if found in mangrove, open country, cloud-forest, pine-oak forest; I, Navarro (1992), "Rare" species (one or two observations) excluded, species assigned 1 if found only in semideciduous forest, species assigned -1 if found in cloud-forest, pine-oak forest, and/or fir forest; $\mathrm{J}$, Stotz et al. (1996), species assigned 1 if found only in TDF, lowland scrub, and/or gallery forest, species assigned -1 if found additionally in second-growth forest and/or other habitat types; K, Monroe (1968), species assigned 1 if restricted to natural vegetation and found exclusively in Pacific Slope tropical deciduous forest and/or thorn-scrub (includes some spillover into adjoining arid interior valleys), species assigned -1 if found in open or disturbed areas and/or other habitats; L, Howell and Webb (1995), species assigned 1 if restricted to arid to semi-humid woodlands, thorn-forest, edge, species assigned -1 if found in any of second-growth, pine or oak forest, plantations, cloudforest, mangroves, open or semi-open areas; M, Land (1970), species assigned 1 if restricted to Pacific lowland and/or arid interior regions and habitat limited to any combination of woodland, scrub, edge, thickets, species assigned -1 if found in any of plantations, second-growth, open woodland, brushy fields. 


\section{References}

Alvarez del Toro, M. (1971) Las aves de Chiapas. Tuxtla Gutierrez, Chiapas, Mexico: Government of the state of Chiapas.

AOU. (1998) Checklist of North American birds. Seventh edition. Washington, D.C.: American Ornithologists' Union.

Arizmendi, M. d. C., Berlanga, H., Márquez-Valdelamar, L., Navarijo, L. and Ornelas, J. F. (1990) Avifauna de la region de Chamela, Jalisco. Mexico, D.F.: Universidad Nacional Autónoma de México.

Binford, L. C. (1989) A distributional survey of the birds of the Mexican state of Oaxaca. Washington, D.C.: American Ornithologists' Union (Orn. Monogr. 43.).

Bojórquez-Tapia, L. A., Azuara, I., Ezcurra, E. and Flores-Villela, O. (1995) Identifying conservation priorities in Mexico through geographic information systems and modeling. Ecol. Appl. 5: 215-231.

Bullock, S. H., Mooney, H. A. and Medina, E., eds. (1995) Seasonally dry tropical forests. Cambridge, U.K.: Cambridge University Press.

Ceballos, G. and García, A. (1995) Conserving Neotropical biodiversity: The role of dry forests in western Mexico. Conserv. Biol. 9: 1349-1353.

Daniels, R. J. R., Hedge, M., Joshi, N. V. and Gadgil, M. (1991) Assigning conservation value: a case study from India. Conserv. Biol. 5: 464-475.

Dickey, D. R. and Van Rossem, A. J. (1938) The birds of El Salvador. Chicago, IL: Field Museum of Natural History (Zoologicat Series 23).

Escalante, B. P. (1988) Aves de Nayarit. Mexico, D.F.: Universidad Nacional Autónoma de México.

Gómez de Silva, H. (1996) The conservation importance of semiendemic species. Conserv. Biol. 10: 674-675.

Hazevoet, C. J. (1996) Conservation and species lists: taxonomic neglect promotes the extinction of endemic birds, as exemplified by taxa from eastern Atlantic islands. Bird Conserv. Internatn. 6: 181-196.

Howell, S. N. G. and Webb, S. (1995) A guide to the birds of Mexico and northern Central America. Oxford: Oxford University Press.

Hutto, R. L. (1992) Habitat distributions of migratory landbird species in western Mexico. Pp. 221-239 in J. M. Hagan, III and D. W. Johnston, eds. Ecology and conservation of neotropical migrant landbirds. Washington, D.C.: Smithsonian Institution Press.

Hutto, R. L. (1995) Can patterns of vegetation change in western Mexico explain population trends in western Neotropical migrants? Pp. 48-58 in M. Wilson and S. Sader, eds. Conservation of Neotropical migratory birds in Mexico. Maine, U.S.A.: Maine Agriculture and Forestry Experimental Station.

Johnson, N. (1995) Defining priorities for conservation and sustainable use. Pp. 932-942 in V. H. Heywold, ed. Global biodiversity assessment. Cambridge, U.K.: Cambridge University Press.

Land, H. C. (1970) The birds of Guatemala. Wynnewood, PA: Livingston.

Lesica, P. and Allendorf, F. W. (1995) When are peripheral populations valuable for conservation? Conserv. Biol. 9: 753-760.

Levey, D. J., and Stiles, F. G. (1992) Evolutionary precursors of long-distance migration: Resource availability and movement patterns in neotropical landbirds. Am. Nat. 140: 447-476.

Loiselle, B. A. and Blake, J. G. (1991) Temporal variation in birds and fruits along an elevational gradient in Costa Rica. Ecology 72: 180-193.

Lynch, J. F. (1992) Distribution of overwintering nearctic migrants in the Yucatan Peninsula, II. Use of native and human-modified vegetation. Pp. 178-196 in J. M. Hagan, III and D. W. Johnston, eds. Ecology and conservation of neotropical migrant landbirds. Washington, D.C.: Smithsonian Institution Press. 
Monroe, B. L. Jr. (1968) A distributional survey of the birds of Honduras. Washington, D.C.: American Ornithologists' Union (Orn. Monogr. 7).

Navarro, S. A. G. (1992) Altitudinal distribution of birds in the Sierra Madre del Sur, Guerrero, Mexico. Condor 94: 29-39.

Ornelas, J. F. and Arizmendi, M. d. C. (1995) Altitudinal migration: implications for the conservation of the Neotropical migrant avifauna of western Mexico. Pp. 98-112 in M. Wilson and S. Sader, eds. Conservation of Neotropical migratory birds in Mexico. Maine, U.S.A.: Maine Agriculture and Forestry Experimental Station.

Ornelas, J. F., Arizmendi, M. d. C., Márquez-Valdelamar, L., Navarijo, M. d. L. and Berlanga, H. A. (1993) Variability profiles for line transect bird censuses in a tropical dry forest in Mexico. Condor 95: 422-441.

Petit, D. R., Petit, L. J. and Smith, K. G. (1992) Habitat associations of migratory birds overwintering in Belize, Central America. Pp. 247-256 in J. M. Hagan, III and D. W. Johnston, eds. Ecology and conservation of Neotropical migrant landbirds. Washington, D.C.: Smithsonian Institution Press.

Powell, G. V. N. and Bjork, R. D. (1995) Implications of intra-tropical migration on reserve design: a case study using Pharomachrus mocinno. Conserv. Biol. 9: 354-362.

Pulliam, H. R. (1988) Sources, sinks, and population regulation. Am. Nat. 132: 652-661.

Ramamoorthy, T. P., Bye, R., Lot, A., Fa, J., eds. (1993) Biological diversity of Mexico. Oxford: Oxford University Press.

Rodríguez, J. P., and Rojas-Suárez, F. (1996) Guidelines for the design of conservation strategies for the animals of Venezuela. Conserv. Biol. 10: 1245-1252.

Rojas, M. (1992) The species problem and conservation: what are we protecting? Conserv. Biol. 6: $170-178$.

Russell, S. M. (in press) Birds of the tropical deciduous forest. In R. H. Robichaux, ed. The tropical deciduous forests of northwestern Mexico: diversity and conservation of a threatened ecosystem. Tucson, AZ: University of Arizona Press.

Rzedowski, J. (1978) Vegetación de México. México, D.F.: LIMUSA.

Sisk, T. D., Launer, A. E., Switky, K. R. and Ehrlich, P. R. (1994) Identifying extinction threats: global analyses of the distribution of biodiversity and the expansion of the human enterprise. Bioscience 44: 592-604.

Stiles, F. G., 1983. Birds. Pp. 502-544 in D. H. Janzen, ed. Costa Rican natural history. Chicago, IL: University of Chicago Press.

Stotz, D. F., Fitzpatrick, J. W., Parker, T. A. III and Moskovits, D. K. (1996) Neotropical birds: ecology and conservation. Chicago, IL: University of Chicago Press.

CALEB E. GORDON

Department of Ecology and Evolutionary Biology, BSW 310, University of Arizona, Tucson, AZ 85721 , U.S.A.

JUAN FRANCISCO ORNELAS

Departamento de Ecología y Comportamiento Animal, Instituto de Ecología, A. C., Apartado Postal 63, Km 2.5 antigua carretera a Coatepec, Xalapa, Veracruz, 91000 México. 
